\title{
Treatment of ovarian cysts in buffaloes with emphasis to echotexture analysis
}

\begin{abstract}
The present study was conducted on 31 buffalo-cows aged 3-10years and diagnosed rectally as they had follicular cyst. The previous diagnosis of the follicular cyst was confirmed by ultrasonography and serum progesterone assay. Ultrasound images of the ovarian follicles, both mature and cystic follicles, were individually identified and monitored and were subsequently digitized for computer analysis of echotexture [mean pixel value (MPV) and pixel heterogeneity (PH)] of the follicle antrum and wall. Animals were classified into two groups (Treated, $n=20$ and control, $n=11$ ). The treated buffalo-cows injected i.m with $100 \mathrm{mg}$ progesterone oily in nature followed by i.m injection of $5000 \mathrm{IU}$ HCG at days 5 . Out of the twenty treated animals 14 buffaloes responded and diagnosed as they had luteinized cyst. Out of the 14 animals that had luteinized cyst 9 buffaloes injected with $25 \mathrm{mg}$ of $\mathrm{PGF}_{2} \alpha$ at day 14 and the other 5 buffaloes left as control. The 6 non responded buffaloes were classified into two subgroups each $(n=3)$, one of them injected with HCG and the other left as control without any treatment. The time elapsed till luteinization of the follicular treated group was significantly different ( $32.67 \pm 1.45$ days and $15.71 \pm 0.75$ days respectively). The recovery rate was $27.27 \%$ in control animals and $70 \%$ in treated ones. Days elapsed till appearance of estrus was significantly shorter in treated buffaloes (22.20 1.19 days) in comparison to the control ones (56.33 \pm 2.03 days). The conception rates were $33.33 \%$ and $66.67 \%$ in control and treated group respectively. Days elapsed from the treated animals ( $36.50 \pm 1.47$ days) compared to the control ones (64days). Serum progesterone level was significantly different in treated animals comparing to the control ones. Changes in echotexture of bovine ovarian follicles assessed by computer analysis of ultrasound images has revealed a significant increase in echotexture parameters (MPV \& $\mathrm{PH}$ ) in cystic follicles compared with preovulatory follicles. $\mathrm{PH}$ of the antrum and wall of luteinized cystic follicles increased significantly compared to preovulatory and cystic follicles. Ultrasonography examination and echotexture analysis has revealed a presence of positive correlation between the cyst wall thickness and progesterone level which consequently aids in the treatment protocol. From the present study, it could be recommended that accurate diagnosis of the ovarian cyst was done by ultrasonography in combination with echotexture characteristics of ultrasound images together with progesterone profile 2 weeks postpartum early as soon as possible; and the animals should be re-examined with 7-10days if possible for re-treatment of non responded cases if necessary.
\end{abstract}

Keywords: ovaries, follicular cysts, buffaloes, echotexture analysis, ultrasonography
Volume 2 Issue 2 - 2015

\author{
Noseir WMB,' Sosa GA M² \\ 'Theriogenology Department, Alexandria University, Egypt \\ ${ }^{2}$ Theriogenology Department, Zagazig University, Egypt
}

Correspondence: Wael MB Noseir, Faculty of Veterinary Medicine, Alexandria University, Egypt, Tel +20 1010993995 Email wnoseir@alexu.edu.eg

Received: March 07, 2015 | Published: May 05, 2015
Abbreviations: MPV, mean pixel value; $\mathrm{PH}$, pixels heterogeneity; COD, cystic ovarian disease; PRID, progesterone intravaginal device

\section{Introduction}

Cystic ovarian disease (COD) in bovine is defined as the presence of large follicle-like structure on one of the ovaries having a diameter of $2.5 \mathrm{~cm}$ or greater, that persists for at least 10days, in the absence of luteal tissue. ${ }^{1}$ However recent evidence from ultrasound studies has shown that all cows with cysts conform to this definition. It appears that some cysts are less than $25 \mathrm{~mm}$ in diameter and do not always persist for as long as 10 days. $^{2}$ COD remains an important cause of the extension of the interval from calving to conception ${ }^{3}$ and increased number of inseminations per conception thus decreased the reproductive performance. ${ }^{4}$ The disease is a common condition of dairy cattle characterized by ovulatory failure. ${ }^{1}$ Their incidence ranged from $5 \%$ to $8 \% .{ }^{5} \mathrm{COD}$ is more common in the early post partum period (less than 60 days) at which cows are under great metabolic stress. ${ }^{6}$ Many factors have been associated with COD although their exact mechanism of action is not known. These factors include, high milk production, ${ }^{7}$ a sever negative energy balance and ketosis, ${ }^{4,7,8}$ twinning and periparturient problems ${ }^{9}$ genetic predisposition, ${ }^{10}$ season, ${ }^{6}$ and nutritional disorders ${ }^{11}$ suggested that, COD results from the failure of the pituitary gland to release sufficient amounts of $\mathrm{LH}$ to induce ovulation.

However many studies of the endocrine profiles of cows with COD, showed that, concentrations of serum LH are high ${ }^{12}$ or normal ${ }^{13}$ serum FSH are low or normal, ${ }^{12,14}$ and serum inhibin are high. ${ }^{13}$ In addition to the alteration in gonadotropin levels, there is a deficiency in LH and FSH receptors at the ovarian level. ${ }^{15}$ Many treatment strategies have been used to resolve the cystic condition. These include manual rupture, dexamethasone, progesterone $\mathrm{GnRH}, \mathrm{hcG}$ and $\mathrm{PGF}_{2} \alpha^{16}$ $\mathrm{GnRH}$ is currently the treatment of choice for undifferentiated COD. ${ }^{16,17} \mathrm{PGF}_{2} \alpha$ alone is the treatment of choice for luteal cysts. ${ }^{18} \mathrm{~A}$ new protocol $\mathrm{GnRH} / \mathrm{PGF}_{2} \alpha \mathrm{GnRH}$ (ovsynch) has also been used to 
treat COD. ${ }^{19}$ The use of progesterone for treatment of COD has been well documented and is known to relieve COD..$^{20,21}$

Computers have been used for quantitative measurement of changes in ultrasonographic morphology ${ }^{22}$ and echotexture ${ }^{23}$ of the reproductive tissues. The present study was designed to evaluate the efficacy of progesterone-hcG combination in treatment of ovarian follicular cyst with the aid of rectal palpation, diagnostic ultrasound, echotexture analysis of ultrasound images and progesterone profile.

\section{Materials and methods}

The present work was carried out on 31 Egyptian buffalo-cows (aged 3-10years) diagnosed as follicular cyst. Animals from the veterinary clinics of Faculty of Veterinary Medicine (Moshtohor \& Alexandria Universities) were studied during the period from January to October 2003. Cystic ovaries were diagnosed by palpation per rectum a cystic structures more than $2.5 \mathrm{~cm}$ in diameter of follicular antrum on one or both ovaries and persisted for three successive examinations. Ultrasonography examination was performed at 7 days interval in the absence of a corpus luteum. ${ }^{24}$ Confirmatory diagnosis by progesterone determination was done using RIA technique ${ }^{25}$ after collection of blood samples twice (at the time of initial diagnoses and 7 -14days later). The level of progesterone was $<1.0 \mathrm{ng} / \mathrm{ml}$ for follicular cyst and $>1.0 \mathrm{ng} / \mathrm{ml}$ for luteal cysts. Animals under investigation were in good body condition, healthy, had no history of other reproductive disorders or treatment with other hormones.

\section{Following diagnosis, animals were classified into two main groups (treated and control) as follows}

Group I (treated animals): Twenty buffalo cows with follicular cyst were injected with $100 \mathrm{mg}$ Progesterone oily in nature (Lutone, Misr Comp. for pharm., Egypt) followed by im injection of $5000 \mathrm{IU}$ hcG at day 5 (Proffassi, E.I.P.I. Co, Egypt) to induce luteinization, from the fourteen responded animals nine were injected $25 \mathrm{mg} \mathrm{PGF} \mathrm{P}_{2} \alpha(\mathrm{Lu}-$ talyse, Upjohn, Belgium) at 14days, while the remaining five animals were left as control. The non-responded buffalo-cows (6 out of 20) to progesterone and hcG were classified into two subgroups (each included 3 animals) one of which was injected hcG and the other one left as control.

Group II (control animals): Eleven buffalo cows with follicular cyst were injected with saline. The observation of a CL was substantiated by an increase in serum progesterone to a level above $1 \mathrm{ng} / \mathrm{ml}$. The positive ovarian response to treatment or recovery was defined by formation of CL 7-14days after stop of progesterone injection ${ }^{26,27}$ or luteinization of the cyst which characterized by increased cyst wall thickness with granular echogenic appearance as visualized by ultrasound ${ }^{27}$ or by an increase in serum progesterone correlated to the presence of a cyst and absence of CL. Animal that did not come in heat, and had a CL on the ovary, which was palpated per rectum or scanned ultrasonography 12-14days after progesterone treatment was stopped, were considered responded to the treatment as well. A negative ovarian response or no recovery was defined by persistence of cyst or development of a new one without luteal progress, absence of both estrus and no CL 14days after progesterone injection was stopped. ${ }^{26,28}$ The obtained data of CL appearance, cyst disappearance, and some fertility indices (appearance of estrus, conception rate, and No. of services per- conception) were statistically analyzed according to Shedecor \& Cochran ${ }^{29}$ using chi-square and student " $t$ " test for significance evaluation of the treatment. ${ }^{29}$

\section{Echotexture analysis of ultrasound images}

Ultrasound images of ovarian follicles were saved to a floppy disk for later computer analysis. Special software was used for analysis of ultrasound images (Scion Image for Windows V 4.0, based on NIH Image for Macintosh. National Institute of Health, USA). The software was designed to quantify characteristics of user- selected regions. Pierson \& Adams ${ }^{22}$ defined echotexture in terms of mean pixel value (MPV) and pixel heterogeneity $(\mathrm{PH}){ }^{22}$ Mean pixel value (average of gray-scale values) was quantified using values ranging from 0 (black) to 255 (White), and the degree of deviation from the mean (standard deviation) of pixel values within the user-defined region was used as indicator of heterogeneity. Greater standard deviation was taken as indication of greater heterogeneity among pixel values within selected regions. Evaluation of the follicle antrum involved sampling a circular region covering $80 \%$ of each quadrant of each image of the antrum (Figure 1). Evaluation of images of the follicle wall involved sampling from two circle regions (Figure 1) within 10 and 2 o'clock positions. ${ }^{30,31}$ Statistical analysis for MPV and $\mathrm{PH}$ was carried out using ANOVA, while multiple comparisons were made by LSD. Pearson's correlation coefficients were used to examine the relationship between ultrasound image attributes. ${ }^{32}$
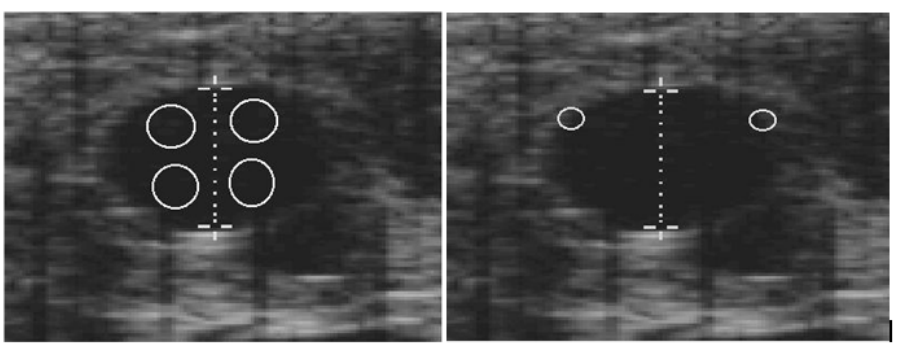

Figure I Sample regions for image analysis of the follicle antrum (left), and wall (right).

\section{Results}

Thirty one buffalo-cows diagnosed rectally to have follicular cyst and confirmed by serum progesterone and ultrasonography. Rectal diagnosis of follicular cyst was based on the presence of single or multiple follicular structure of at least $25 \mathrm{~mm}$ in diameter on one or both ovaries in the absence of CL. Ultrasonography examination revealed that, the follicular cyst appeared as an uniformly nonechogenic ovarian structure $\geq 25 \mathrm{~mm}$ in diameter with a wall $<3 \mathrm{~mm}$ (Figure 2). Serum progesterone confirms the diagnosis of follicular cyst as their level $<0.9 \mathrm{ng} / \mathrm{ml}$. Out of 20 treated buffalo cows 14 (70\%) were diagnosed sonographically and confirmed by serum progesterone to have luteinized cyst within 11-18day (15.71 \pm 0.75 days). The other 6 buffalo-cows, which not responded to the treatment, were classified into two subgroups ( 3 animals treated with hCG and 3 animals left without treatment as control). The recovery rate was $33.33 \%$ in both subgroups (indicated with presence of CL formation and appearance of estrus in animals treated with hCG and CL formation without estrus) in control subgroup. Out of 11 control animals 3(27.27\%) have luteinized cyst within 30-35days (32.67 \pm 1.45 days) (Table 1).

The 14 buffalo-cows, which have luteinized cyst, classified into two subgroups (the first, 9 animals injected i.m. with $\mathrm{PGF}_{2} \alpha$ and the second, 5 animals left without treatment). Out of 9 animals treated with $\mathrm{PGF}_{2} \alpha 7$ animals $(77.78 \%$ ) came in estrus earlier. Three animals $(60 \%)$ out of 5 -control subgroup came in estrus later. The other 6 buffalo-cows, which not responded to the treatment, were classified 
into two subgroups ( 3 animals treated with hcG and 3 animals left without treatment as control). The recovery rate was $33.33 \%(1 / 3)$ in both subgroups (indicated with presence of CL formation and appearance of estrus in animals treated with hcG and CL formation with no heat in control subgroups). The days to estrus appearance was $22.20 \pm 1.19$ days in treated animals and $56.33 \pm 2.03$ days in control one. The conception rate was significantly $(66.67 \%)$ in the treated group than in the non-treated one $(33.33 \%)$. Days elapsed to conception was increased (64days) in control animals than in treated one (36.5 \pm 1.47 days).
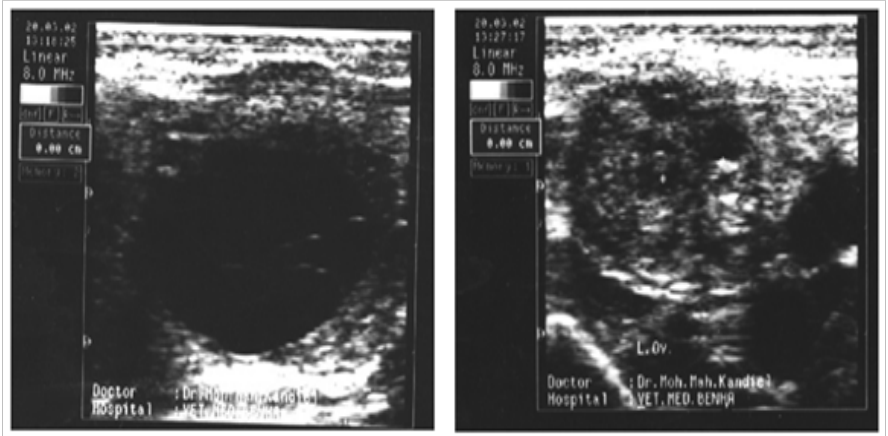

Figure 2 Large follicular cyst $>25 \mathrm{~mm}$ in diameter (Left), and luteinized follicle (Right).

Table I Clinical findings in animals with follicular ovarian cyst

\begin{tabular}{|c|c|c|}
\hline Criteria & Control $(n=I I)$ & Treated $(n=20)$ \\
\hline & $32.67 \pm 1.45^{\mathrm{a}}$ & $|5.7| \pm 0.75^{b}$ \\
\hline \multicolumn{3}{|c|}{$\begin{array}{l}\text { Days till Appearance of } \\
\text { Luteinized Cyst }\end{array}$} \\
\hline & $(30-35)$ & $(11-18)$ \\
\hline & II-Mar & $14 / 20$ \\
\hline \multicolumn{3}{|l|}{ Recovery Rate } \\
\hline & $27.27 \%$ & $70.00 \%$ \\
\hline \multirow[t]{2}{*}{ Days to Estrus } & $56.33 \pm 2.03^{\mathrm{a}}$ & $22.20 \pm 1.19^{b}$ \\
\hline & 3-Jan & $14-O c t$ \\
\hline \multicolumn{3}{|l|}{ Conception Rate } \\
\hline & $33.33 \%$ & $66.67 \%$ \\
\hline Days to Conception & $64.00 \pm 0.00^{\mathrm{a}}$ & $36.50 \pm 1.47^{b}$ \\
\hline
\end{tabular}

Values with different alphabetic within the same raw were significantly different at $\mathrm{P}<0.05$

The mean level of serum progesterone in responded and non responded follicular cysts of treated animals was significantly differed at 7 days pre treatment and 14 days post treatment with progesterone and hcG; and 7days post treatment with $\mathrm{PGF}_{2} \alpha$ in previously responded animals. Regarding the effect of the treatment on responded follicular cyst (Table 2), the progesterone level was significantly

increased $(\mathrm{P}<0.01)$ 14days post treatment with progesterone and hCG $(1.40 \pm 0.03 \mathrm{ng} / \mathrm{ml})$ in comparison to their level at 7days pre treatment $(0.35 \pm 0.02 \mathrm{ng} / \mathrm{ml})$ and 7 days after $\mathrm{PGF}_{2} \alpha$ showed significant decrease $(\mathrm{P}<0.01)$ in serum progesterone level $(0.41 \pm 0.03 \mathrm{ng} / \mathrm{ml})$ compared to their level before $\mathrm{PGF}_{2} \alpha$ injection. The level of progesterone in non responded cases significantly increased $(\mathrm{P}<0.01)$ at day 14 post treatment with progesterone and $\mathrm{hCG}(0.59 \pm 0.02 \mathrm{ng} / \mathrm{ml})$ compared to that 7 days pre treatment $(0.42 \pm 0.01 \mathrm{ng} / \mathrm{ml})$.

The mean level of progesterone was significantly decreased $(\mathrm{P}<0.01)$ in animal injected with $\mathrm{PGF}_{2} \alpha(0.41 \pm 0.02 \mathrm{ng} / \mathrm{ml})$ compared to their level before $\mathrm{PGF}_{2} \alpha$ injection. On the other hand progesterone level significantly increased $(\mathrm{P}<0.01)$ in non responded animals after injection of hcG $(0.61 \pm 0.03 \mathrm{ng} / \mathrm{ml})$ compared to their level before hcG injection $(0.59 \pm 0.02 \mathrm{ng} / \mathrm{ml})$. The relationship between progesterone level and the thickness of the cyst wall was positively correlated as the cyst wall thickness increased the progesterone level increased.

Table 2 The mean level of serum progesterone $(\mathrm{ng} / \mathrm{ml})$ in treated group

\begin{tabular}{lll}
\hline Criteria & $\begin{array}{l}\text { Responded } \\
\text { follicular cyst }\end{array}$ & $\begin{array}{l}\text { Unresponded } \\
\text { follicular cyst }\end{array}$
\end{tabular}

7days Pre-treatment with Progression and hcG

$0.35 \pm 0.02 c$

$0.42 \pm 0.0 \mathrm{lb}$

I4days Post Treatment with $\quad 1.40 \pm 0.03 a \quad 0.59 \pm 0.02 * * a$
Progesterone and hcG

7days Post Treatment with $\mathrm{PGf}_{2} \alpha$

\section{$0.4 I \pm 0.02 b \quad 0.61 \pm 0.03 a$}

\section{**Significant difference within the same raw}

Values with different alphabetic within the same column were significantly different at $\mathrm{P}<0.05$

Results of echotexture analysis of ultrasound images of ovarian follicles have shown that there was a significant $(\mathrm{P}<0.001)$ increase in MPV of the wall of luteinized cystic follicles compared with preovulatory and cystic follicles (Figure 3), while there was a non significant decrease in MPV of the wall of cystic follicles compared to preovulatory follicles. There was a significant correlation between MPV and PH of the follicle wall $(r=0.84, r=0.81$, respectively, $\mathrm{P}=0.001)$ and antrum $(\mathrm{r}=0.80, \mathrm{r}=0.79$, respectively, $\mathrm{P}=0.001)$, with the advancement of follicular development [preovulatory, cystic, then luteinized cystic follicles] (Figure 4).

A significant increase in MPV and PH of the follicle antrum was observed in the luteinized cystic follicles compared with preovulatory and cystic follicles (Figure 3) (Figure 4). On the other hand, changes in $\mathrm{PH}$ of the wall and antrum of cystic follicles were not significant compared with preovulatory follicles, while a significant increase was observed in PH values of the wall and antrum of luteinized cystic follicles compared with cystic follicles (Figure 4). A significant correlation was also observed between MPV of the wall of luteinized cystic follicles and serum progesterone level $(\mathrm{r}=0.87, \mathrm{P}<0.001)$. 

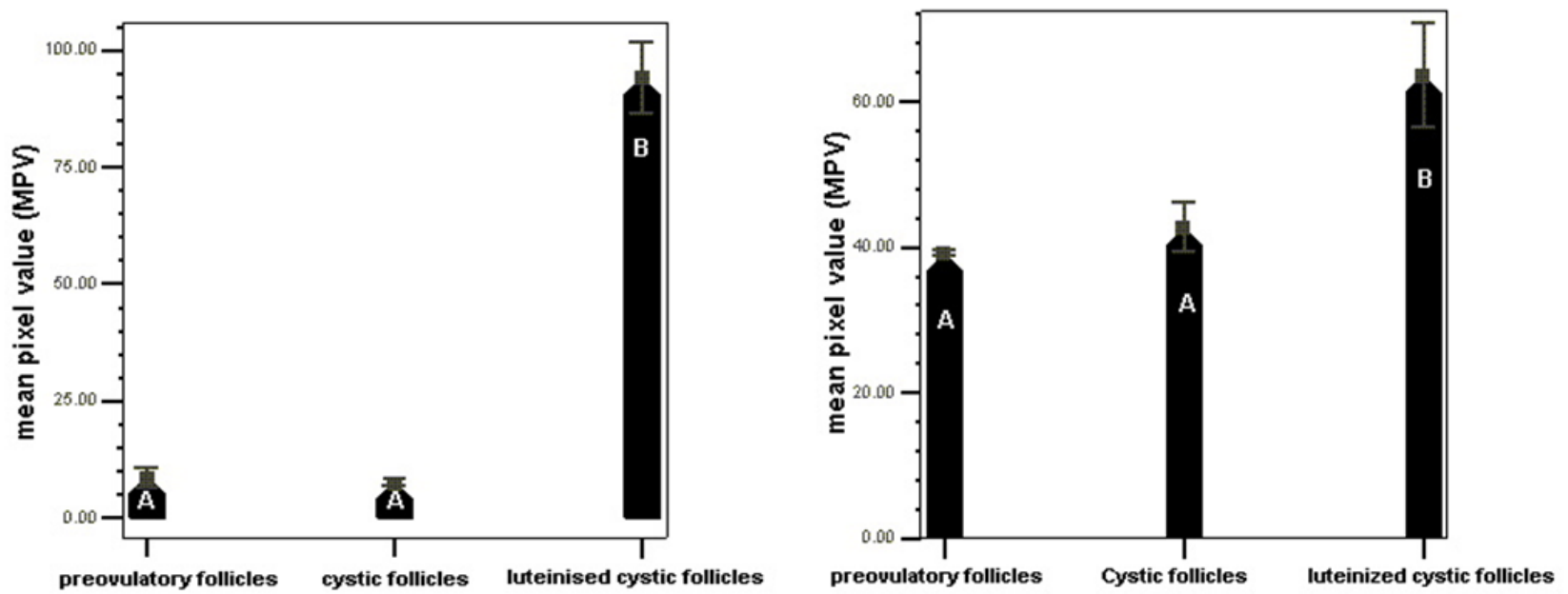

Figure 3 Mean pixel value (MPV) of the wall (Left) and antrum (Right) of ovarian follicles (preovulatory, cystic, and luteinized cystic follicles). Bars are means \pm SEM. Bars with no common letters are significantly different $(P<0.00 \mathrm{I})[\mathrm{LSD}]$.

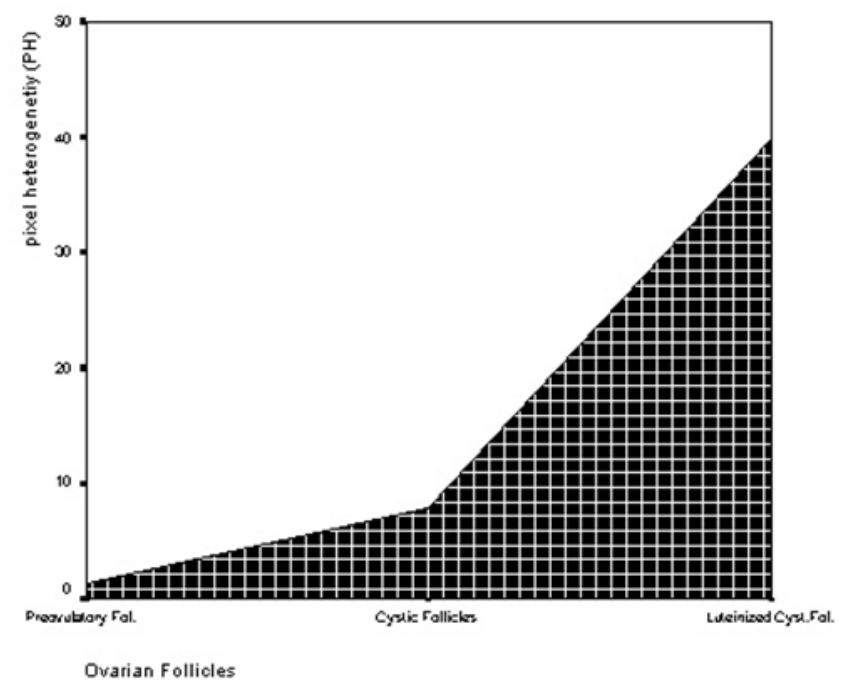

Figure 4: Pixel Heterogeneity $(\mathrm{PH})$ of the wall and antrum of ovarian follicles (preovulatory, cystic, and luteinized cystic follicles).

\section{Discussion}

Ovarian cysts were diagnosed clinically on the basis of behavioral abnormalities and rectal palpation of the ovaries confirmed with progesterone and ultrasonography. These findings came in accordance with Ridabu et al. ${ }^{33}$ In the same aspect Jeffcoate \& Ayliffe ${ }^{21}$ found that, plasma progesterone concentration was a useful adjunct to ultrasound interpretation of the cysts serum progesterone concentration was similar for cows diagnosed by rectal palpation as having luteal cysts compared with those having follicular cysts. ${ }^{2}$

They added that, diagnosis of cysts by ultrasonography showed higher progesterone level for luteal cysts $(1.01 \pm 0.16 \mathrm{ng} / \mathrm{ml})$ than for follicular cysts $(0.30 \pm 0.01 \mathrm{ng} / \mathrm{ml})$. The successful treatment of cysts was utilized by crud pituitary extracts that were high in LH content, human chorioric gonadotropin (hCG) with a success rate of 65 to $80 \%,{ }^{34}$ synthetic $\mathrm{GnRH}$ analogues with success about $80 \%{ }^{28,35}$ and administration of progesterone for treatment of the thin wall non estrogenic cyst. ${ }^{36,37}$ The present study revealed that, $70 \%$ of treated buffalo-cows having luteinized cyst within 11-18days. The recovery rate was similar to those observed after GnRH $70-80 \% .^{16}$

These findings came in agreement with Nakao et al. ${ }^{28}$ Luteotropic agents as hCG and $\mathrm{GnRH}$ in case of follicular cysts to induce luteinization..$^{28}$ They also explained that, the combined treatment of follicular cysts with $1500 \mathrm{IU}$ hcG/150mg progesterone or 5000IU $\mathrm{hcG} / 300 \mathrm{mg}$ progesterone was effective even when performed long after calving and recommended for practical application. Recently, Zulu et al. ${ }^{27}$ concluded that, exogenous progesterone might play a role in restoring hypothalamus sensitivity, to estradiol in cows with ovarian cysts. ${ }^{27}$ Additionally Nanda et al. ${ }^{20}$ reported that, there was no difference in recovery rates between treatment of follicular cyst with GnRH and progesterone intravaginal device (PRID). ${ }^{20}$ The recovery rate in the other non-responded animals was $33.33 \%$ if treated with hCG injection. This might explained that, injection of hCG during luteal phase caused delayed regression of CL or the cows having luteinized cysts and treated with hCG need longer period to exhibit estrus than their herd mates. ${ }^{34}$

The present study revealed that the recovery rate of control animals was $27.27 \%$. These findings came in accordance with Bierschwal et al..$^{38}$ and Garverick ${ }^{39}$ who found that, approximately $20 \%$ of cows with cysts spontaneously resume ovulatory ovarian cycles. In the same respect, Jou et al. ${ }^{1}$ reported that, the follicular cysts do not interfere with normal ovarian function. Other researchers recorded that, $15 \%$ of dairy cows showed ovarian cysts during the early postpartum period and in most cases these cysts disappear spontaneously while in the remainder initiation of the cycle in inhibited. ${ }^{40}$ Animals showing luteinization of the cyst and injected with $\mathrm{PGF}_{2 \alpha}$ came in estrus with a recovery rate $77.78 \%$ and their conception rate was $66.67 \%$.

Similar results were obtained by Garverick ${ }^{39}$ at which cysts responded to hCG or GnRH by leutinization of the cystic structure, $\mathrm{PGF}_{2} \alpha$ cause lysis of luteinized cysts. These findings were supported by Kesler and Garverick ${ }^{41}$ Nada et al. ${ }^{20}$ and Archibald et al. ${ }^{42}$ who reported that, $\mathrm{PGF}_{2} \alpha$ appeared to be more effective in inducing luteolysis when given 9 to 14 days after GnRH or hCG than when given earlier. The days to estrus and conception was significantly $(\mathrm{P}<0.01)$ shorter in treated animals than in control ones. 
These finding came in accordance with Kesler \& Garverick $^{41}$ and Zulu et al. ${ }^{27}$ Similarly Nakao et al. ${ }^{28}$ found beneficial effect of the GnRH-PGF $\alpha$ combination in the treatment of follicular cysts resulted in shorter intervals from treatment to estrus, as well as conception and higher conception rates in comparison to the untreated animals. ${ }^{28}$ The luteinized cysts responded very rapidly to $\mathrm{PGF}_{2} \alpha$ treatment, collapsing within 2-4days and the newly formed CL were observed within one week after the treatment confirmed by a rapid decrease of plasma progesterone. ${ }^{21}$ On the other hand, Stolla et al. ${ }^{43}$ disagreed with the previous results and could not record any beneficial effect of $\mathrm{PGF}_{2} \alpha$ given 14days after $\mathrm{GnRH} .{ }^{43}$

The present study revealed that there was a positive correlation between the thickness of cyst wall and progesterone level. These findings come in agreement with Douthwaite \& Dobson. ${ }^{36}$ Thickwalled cyst produce progesterone whereas thin-walled cyst in the absence of other follicles of more than $5 \mathrm{~mm}$ diameter produce estradiol, but thin-walled cyst in the presence of other follicles of more than $5 \mathrm{~mm}$ diameter are not estrogenic. ${ }^{44-46}$ All thick-walled cysts should respond immediately to $\mathrm{PGF}_{2} \alpha \cdot{ }^{35}$ On the other hand, Tebble et al., ${ }^{37}$ found no influence of follicular cyst wall thickness on the outcome of treatment either with GnRH or PRID. ${ }^{37}$

Computer-assisted echotexture analysis offers the potential of a highly sensitive and quantitative method of assessing follicular and luteal status. ${ }^{22,23}$ Changes in pixel values and pixel heterogeneity of the follicle antrum and wall were documented and specific correlations were assessed between them and serum progesterone levels. MPV obtained by spot analysis of the antrum, is a measure of the overall (average) gray-scale value of the pixels falling under the measuring circle, while $\mathrm{PH}$ of the antrum is a measure of the variation in grayscale value of pixels falling under the measuring circle. Luteinized cysts have a thicker wall than non luteinized cysts; this thick wall of luteal cysts is composed of luteal tissue. ${ }^{39}$ In the present study, a significant increase was observed in MPV of the wall and antrum of luteinized follicles compared to cystic and preovulatory follicles. Similar results were reported by Schrick et al. ${ }^{47}$ who stated that luteal cyst has an obvious wall with a rougher inner lining and has the echotexture of a mature corpus luteum. ${ }^{47}$ They added that the antrum of luteal cysts have an echoic band-like network.

A significant positive correlation between MPV of the wall of luteinized cystic follicles and serum progesterone level was observed in the present study. Similar finding was reported by Singh et al. ${ }^{23}$ who stated that pixel values of ultrasound images were highly correlated to plasma and luteal tissue progesterone concentrations..$^{23}$

\section{Conclusion}

In conclusion the present study evaluate some ultrasound parameters used as diagnostic tool for ovarian cyst in buffaloes with emphasis to the wall thickness in differentiation between follicular and luteal cases and consequently in suggesting the treatment. Ultrasonography and echotexture analysis provides a visible method for evaluating wall thickness and distinguishing types of ovarian follicles in buffaloes, and aid in diagnostic and treatment purposes.

\section{Acknowledgements}

None.

\section{Conflict of interest}

Author declares that there is no conflict of interest.

\section{References}

1. Jou P, Buckrell BC, Liptrap FM, et al. Evaluation of the effect of $\mathrm{GnRH}$ on follicular ovarian cysts in dairy cows using trans-rectal ultrasonography. Theriogenology. 1999;52(5):923-937.

2. Farin PW, Youngquist RS, Parfet JR, et al. Diagnosis of luteal and follicular ovarian cysts by palpation per rectum and linear array ultrasonography in dairy cows. J Am Vet Med Assoc. 1992;1200(8):10851089.

3. Dohoo IR, Martin SW, Meek AH, et al. Disease, production and culling in Holstein-Friesian cows. Prev Vet Med. 1983;1(4):321-334.

4. Oltenacu PA, Frick A, Lindhe B. Epidemiological study of several clinical diseases, reproductive performance and culling in primiparous Swedish cattle. Prev Vet Med. 1990;9(1):59-74.

5. Zduncyk S, Mwaanga ES, Malecki-Tepicht J, et al. Plasma progesterone levels and clinical findings in dairy cows with post-partum anoestrus. Bull Vet Inst Pulowy. 2002;46:79-86.

6. Bartlett PC, Ngategize PK, Kaneene JB, Et Al. Cystic follicular disease in Michigan Holstein-Friesian cattle: incidence, descriptive epidemiology and economic impact. Prev Vet Med. 1986;4(1):15-33.

7. Laporte HM, Hogeveen H, Schukken YH, et al. Cystic ovarian disease in Dutch dairy cattle I. Incidence, risk factors and consequences. Livest Prod Sci. 1994;38(3):191-197.

8. Grohn Y, Erb HN, McCulloch CE, et al. Epidemiology of reproductive disorders in dairy cattle: Associations among host characteristics, disease and production. Prev Vet Med. 1990;8(1):25-39.

9. Bosu WTK, Peter AT. Evidence for a role of intrauterine infections in the pathogenesis of cystic ovaries in postpartum dairy cows. Theriogenology. 1987;28(5):725-736.

10. Ashmawy AA, Vogt D, Youngquist R, et al. Heritability of liability to cystic ovary development in Holstein cattle. J Hered. 1990;81(2):165166.

11. Roberts SJ. Hormonal Disturbances resulting in Infertility. In: SJ Roberts edoitor. Veterinary Obstetrics and Genital Diseases (Theriogenology). Theriogenology, Woodstock, Vietnam; 1986. p. 478-494.

12. Kondoh M, Taya K, Motoya M, et al. Pituitary and ovarian hormones in cows with ovarian cysts. Jpn J Anim Reprod. 1990;36(1):17-25.

13. Roberge S, Brown JL, Reeves JJ. Elevated inhibin concentration in the follicular fluid of dairy cows with chronic cystic ovarian disease. Theriogenology. 1993;40(4):809-818.

14. Dobson H, Rankin JFF, Ward WR. Bovine cystic ovarian disease: plasma hormone concentration and treatment. Vet Rec. 1977;101(23):459-461.

15. Brown JL, Schoenemann HM, Reeves JJ. Effect of FSH treatment on LH and FSH receptors in chronic cystic-ovarian-diseased dairy cows. $J$ Anim Sci. 1986;62(4):1063-1071.

16. Day N. The treatment and prevention of cystic ovarian disease. Vet Med Anim Pract. 1991;86:761-766.

17. Stock AE, Fortune JE. Ovarian follicular dominance in cattle: relationship between prolonged growth of ovulatory follicle and endocrine parameters. Endocrinology. 1993;132(3):1108-1114.

18. Augustin TP. Infertility due to abnormalities of the ovary. In: Youngquist RS editor. Current therapy in large animal Theriogenology. Philadelphia, USA: WB Sounders; 1997. p. 349-354.

19. Bartolome JA, Archbald LF, Morresey P, et al. Comparison of synchronization of ovulation and induction of estrus as therapeutic strategies for bovine ovarian cysts in the dairy cow. Theriogenology. 2000;53(3):815-825. 
20. Nanda AS, Ward WR, Williams PCW, et al. Retrospective analysis of the efficacy of different hormone treatment of cystic ovarian disease in cattle. Vet Rec. 1988;122(7):155-158.

21. Jeffcoate IA, Ayliffe TR. An ultrasonographic study of bovine cystic ovarian disease and its treatment. Vet Rec. 1995;136(16):406-410.

22. Pierson RA, Adams GP. Computer-assisted image analysis, diagnostic ultrasonography and ovulation induction: Strange bedfellows. Theriogenology. 1995;43(1):105-112.

23. Singh J, Pierson RA, Adams GP. Ultrasound image attributes of bovine corpus luteum: structural and functional correlates. J Reprod Fert 1997;109(1):35-44.

24. López-Gatius F, Santolaria P, Yániz J, et al. Risk factors for postpartum ovarian cysts and their spontaneous recovery or persistence in lactating dairy cows. Theriogenology. 2002;58(8):1623-1632.

25. Hoffmann B. Bestimmung von Steroidhormonen beim weiblichen Rind Entwicklung von Messverfahren und physiologische Daten. Fortschritte der Veterinarmedizin, Berlin and Hamburg, Verlage Paul Parey; 1997.

26. Youngquist RS. Cystic follicular degeneration in the cow. In: Morrow DA editor. Current Therapy in Theriogenology. 1986;2:243-246.

27. Zulu VC, Nakao T, Yamada K, et al. Clinical responses of ovarian cys in dairy cows after PRID treatment. J Vet Med Sci. 2003;65(1):57-62.

28. Nakao T, Numata Y, Kubo M, et al. Treatment of cystic ovarian disease in dairy cattle. Cornell Vet. 1978;68(2):161-178.

29. Snedecor GW, Cohran WG. Statistical Method. 7thed. Ames. IA, USA: Iowa state University Press; 1982.

30. Kremkau FW. Diagnostic Ultrasound: Principles, Instruments, and Exercises. Philadelphia: WB Saunders Company; 1989. p. 1-50, 147176, 219-231.

31. Ginther OJ. Ultrasonic imaging and animal reproduction Fundamentals Book 1. Cross Plains WI: Equiservices Publishing; 1995. p. 7-82, 147-155.

32. Norusis MJ. SPSS/PC+ for the IBM PC/XT/AT. Chicago: SPSS Inc; 1986.

33. Ribadu AY, Dobson H, Ward WR. Ultrasound and progesterone monitoring of ovarian follicular cysts in cows treated with $\mathrm{GnRH} . \mathrm{Br}$ Vet J. 1994;150(5):489-497.

34. Seguin BE, Convey EM, Oxender WD. Effect of Gonadotropin releasing hormone and human chorionic gonadotropin on cows with ovarian follicular cysts. Am J Vet Res. 1976;37(2):153-157.
35. Ribadu AY, Ward WR, Dobson H. Comparative evaluation of ovarian structures in cattle by palpation per rectum, ultrasonography and plasma progesterone concentration. Vet Rec. 1994;135(19):452-457.

36. Douthwaite R, Dobson H. Comparison of different methods of diagnosis of cystic ovarian disease in cattle and an assessment of its treatment with a progesterone-releasing intravaginal device. Vet Rec. 2000;147(13):355-359.

37. Tebble JE, O'Donnell MJ, Dobson H. Ultrasound diagnosis and treatment outcome of cystic ovaries in Cattle. Vet Rec. 2001;148(13):411-413.

38. Bierschwal CJ, Garverick HA, Martin CE, et al. Clinical response of dairy cows with ovarian cysts of GnRH. J Anim Sci. 1975;41(6):1660 1665 .

39. Garverick HA. Ovarian follicular cysts in dairy cows. J Dairy Sci. 1997;80(5):995-1004.

40. Lopez-Diaz MC, Bosu WTK. A review and an update of cystic ovarian degeneration in ruminants. Theriogenology. 1992;37(6):1163-1183.

41. Kesler DJ, Garverick HA. Ovarian cysts in dairy cattle: a review. J Anim Sci. 1982;55(5):1147-1159.

42. Archibald LF, Norman SN, Tran T, et al. Does GnRH work as well as GnRH and PGF $2 \alpha$ in the treatment of ovarian follicular cysts? Vet Med. 1991;86:1037-1040.

43. Stolla R, Bostedt H, Wendt V, et al. Cystic ovarian disease in cattle III. Evaluation of different treatment methods. Berl Munch Tierar Woschenschr. 1980;93(1):4-10.

44. Noble K, Douthwaite R, Dobson H. Comparative evaluation of ovarian structures in cattle. Cattle practice. 1994;5:379-380.

45. Scott SJ, Dobson H. Postmortem comparison of ultrasonography, endocrine measurements and histology of large abnormal follicles in cows. Vet Rec. 1997;140(25):654-656.

46. Noble LS, Takayama K, Zeitoun KM, et al. Prostaglandin E2 stimulates aromatase expression in endometriosis-derived stromal cells. J Clin Endocr Metab. 1997;82(2):600-606.

47. Schrick FN, Edwards JL, Blackmon H, et al. Emerging Technologies in Reproduction. In: Reproductive Management Tools and Techniques III. Columbia, MO. Section 8: University of Missouri Outreach and Veterinary Extension and Continuing Education Commercial Agriculture Program; 2001.p. 1-14. 